\title{
Lars Held
}

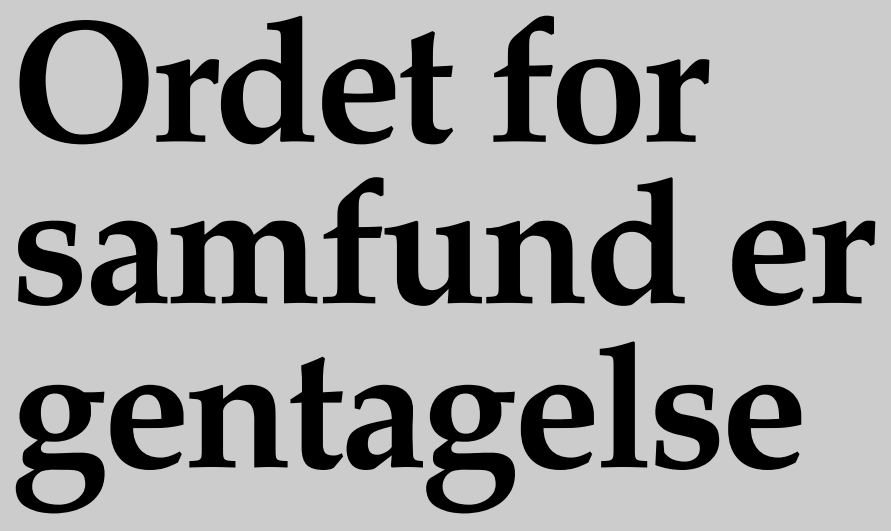

Et centralt element $i$ sociologien er forestillingen om "det sociale" som en selvstændig virkelighed. I en af den sociologiske videnskabs forste metodestridigheder anlagde Émile Durkheim og Gabriel Tarde to vidt forskellige perspektiver på begrebsliggorelsen af denne virkelighed. Med begrebet gentagelse som omdrejningspunkt, vil artiklen diskutere disse to bidrag med henblik på at vise, hvordan Durkheim og Tarde konstruerede det sociale som selvstændigt realitetsniveau gennem hver deres gentagelseskoncept. 
$\mathrm{D}$ enne artikel $^{1}$ vil omhandle en af den sociologiske videnskabs første metodestridigheder, nærmere bestemt den løbende debat mellem Durkheim og Tarde, der udspillede sig i årene omkring århundredeskiftet i Paris. Eftertiden har ikke skænket denne tidlige metodestrid megen opmærksomhed, hvilket måske kan skyldes den ene af disse tænkeres teorihistoriske skæbne. For historien har været særlig hård ved Gabriel Tarde. I sin levetid opnåede han lærestolen i filosofi ved College de France (foran Bergson, der, trods den interne konkurrence, beskrev Tarde som en tænker der "åbnede så vide horisonter for os"), han var medlem af Institut de France og præsident for Internationale Gesellschaften für Soziologie und Rechtwissenschaften og efterlod et livsværk på mere end 15 bind (Alliez 2001). I Park og Burgess' Introduction to the Science of Sociology, fra 1922, er der flere referencer til Tarde end til Comte og Durkheim (Hughes 1961:554). I dag skal man derimod være heldig for at finde Tarde i et sociologisk opslagsværk.

I årene omkring århundredeskiftet var der dog i Frankrigs akademiske kredse stor opmærksomhed omkring denne strid, hvilket ikke kun skyldes, at Durkheim og Tarde repræsenterede henholdsvis Sorbonne Universitet og College de France, to konkurrerende institutioner, der hver især stræbte efter at tilegne sig monopolet på det videnskabelige studie af samfundet. De to tænkere stod også som repræsentanter for to dybt rodfæstede og modsatrettede kulturelle konfigurationer i det franske samfund: cartesianisme og spontanisme (Clark 1969; 1973) $)^{2}$.

Som kulturel konfiguration var cartesianismen forbundet med orden, autoritet og med et program for realiseringen af fornuften gennem statens institutioner. Efter revolutionen og under Napo- leon fandt cartesianismen primært sine tilhængere blandt borgerskabet, der forsøgte at gøre dette verdenssyn til en officiel ideologi. Det var dog især efter etableringen af den Tredje Republik, at cartesianismen fik en stærk institutionel forankring, ikke mindst på Sorbonne. I Durkheim så denne traditions tilhængere en værdig samfundsvidenskabelig repræsentant, der kunne overføre de cartesianske principper til studiet af samfundet. Dertil kom også, at Durkheim havde ydet et ikke uvæsentligt bidrag til udformningen af et verdsligt regeringsprincip for Den Tredje Republik.

I forhold til cartesianismen var spontanismens tilhængere en mere broget forsamling, der talte alt fra anarkistiske revolutionære til romantiske nationalister. Fællestrækkene var en dyrkelse af den menneskelige kreativitet og en generel anti-institutionel og anti-kollektivistisk holdning. Bergson og Sorel var blandt denne konfigurations vigtigste repræsentanter. Det var her Durkheim fandt mange af sine mest indædte politiske og intellektuelle modstandere, hvorimod Tarde her fandt sine stærkeste støtter.

Som Clark har beskrevet omstændighederne omkring den løbende debat mellem Durkheim og Tarde, var der investeret meget intellektuel, politisk og akademisk kapital i disse divergerende positioner. Der kan dog ikke være tvivl om, at det var Durkheim, der løb af med sejren, og at Tarde efterfølgende blev skubbet ud i glemslen ${ }^{3}$. Dette har der selvfølgelig været mange årsager til, f.eks. besad Tarde ikke Durkheims talent for institutionel organisering og skoledannelse. En anden årsag har da også været, at det i vid udstrækning lykkedes Durkheim og hans efterfølgere at stemple Tardes sociologi som "individualistisk" og dermed anti-sociologisk.

I det følgende vil jeg konfrontere Tarde og Durkheims teorier med hinanden. 
Men i stedet for at beskrive deres forskellige perspektiver ud fra forskellen holistisk/individualistisk (Durkheims perspektiv), vil jeg forsøge at se denne strid fra det "mislykkedes perspektiv" og sætte gentagelsesbegrebet ${ }^{4}$ i centrum for diskussionen af de to tænkere. Jeg vil derfor vise, hvordan både Tarde og Durkheim konstruerer det sociale som selvstændigt realitetsniveau gennem hver deres gentagelseskoncept.

\section{Det sociale og gentagelsen: Durkheim}

Det er velkendt, at Weber insisterede på, at det socialvidenskabelige blik for at kunne trænge ind i virkeligheden må passere gennem en idealtype. Durkheim startede et andet sted og søgte adgang til det virkelige via det ideelle. Han etablerede forbindelsen med begrebet om det normale, der forbinder det ideelle og det virkelige gennem frekvenser (Thevenot 2000:2). Denne tilgang placerer et koncept om gentagelse i hjertet af Durkheims teoriopbygning, og han overtog endda, om end for en kort stund og i en polemisk sammenhæng, Tardes betegnelse for den sociale gentagelse, og hævdede, at "ethvert socialt forhold [er] imiteret" (Durkheim 1972:131, note 13).

I dette afsnit vil jeg beskrive tankegangen bag Durkheims sociologiske forståelse af gentagelsens fænomen, med henblik på at konfrontere Durkheim og Tardes teorier med hinanden. Da Durkheim især er blevet kendt for at insistere på det sociales eksternalitet i forhold til individet, ville det umiddelbart være oplagt at beskrive hans forståelse af gentagelsen med udgangspunkt i hans distinktion mellem individ og samfund. Jeg vil i stedet gå den anden vej og vise, hvordan det hos Durkheim netop er inkorporeringen af et specifikt gentagelseskoncept, der muliggør denne distinktion og dermed også muliggør fremlæggelsen af det

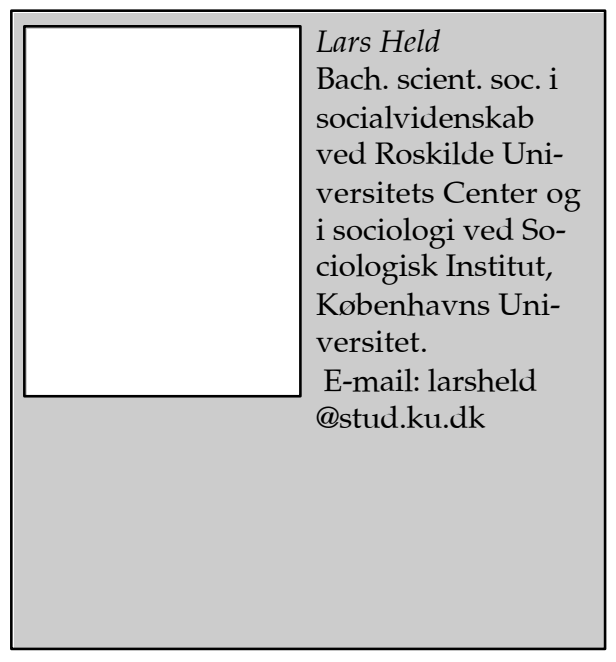

sociale som selvstændigt virkelighedsniveau.

Da Weber i 1904 advarede mod at overføre naturvidenskabelige forklaringsmodeller til sociologiens genstandsfelt, refererede han bl.a. til "en prominent naturvidenskabsmand", der hævdede, at "idealet for kulturanalysen er at tilvejebringe en " "astronomisk" analyse af livets forhold" (Weber i Oberschall 1987: 111). Den formastelige videnskabsmand, som Weber ikke sætter navn på, har uden tvivl været Adolphe Quetelet, men i modsætning til Weber fandt Durkheim stor inspiration i dennes arbejder. Det var måske endda som en særlig hyldest til Quetelet, at Durkheim i Selvmordet hævdede, at individet var underlagt sociale love, der var "virkelige som kosmiske kræfter" (Durkheim 1996:309).

Når det er relevant at redegøre for Quetelets betydning for Durkheim skyldes det, at Durkheim krediterede Quetelet for to ting: for at have været den første til at fremanalysere en selvstændig social realitet bag menneskelige handlinger (Schmaus 1994:270, note 7), og for at have tilvejebragt "den eneste systematiske forklaring" på spørgsmålet om "den forbløffende regularitet hvormed visse sociale fænomener gentager sig" (Durk- 
heim 1996:300). Som vi nu skal se, er der her tale om to sider af samme sag.

Quetelets fundamentale bidrag til samfundsvidenskaben i midten af 1800'tallet bestod i en sammenføjning af to indtil da adskilte vidensformer, sandsynlighedsteori og moralsk statistik.

Fra sandsynlighedsteorien og astronomien importerede Quetelet to veletablerede tankemodeller til studiet af moralske fakta. Den ene bygger på ideen om en urne indeholdende en defineret andel af sorte og hvide bolde (eksempelvis 30 sorte og 70 hvide), hvorfra der udtrækkes, med tilbagelægning, en mængde "stikprøver" (eksempelvis 10 bolde). Sandsynlighedsfordelingen for disse udtræk er binomial og når forsøget gentages mange gange, følger udtrækssandssynligheden (for andelen af sorte kugler) en normalfordeling centreret omkring den sande sandsynlighed (her 3/ 10). Dette udtrykker Bernoullis "Store Tals Lov" (Desrosières 1998:87; Lazarsfeld 1997:194). Fra astronomien hentede Quetelet Gauss' fejlkurve, der beskriver spredningen af gentagede observationer af et himmellegeme som en normalkurve med en middelværdi, der modsvarer den sande observation.

Fælles for disse to tankeskemaer er, at gentagede hændelser (stikprøver, observationer) på tværs af deres variation refererer til en objektiv fællesnævner (urnens komposition, himmellegemets placering), som tilskrives ontologisk primat i forhold til de individuelle, empiriske manifestationer. Ved at forbinde gentagelser (stikprøver) med en underliggende sandsynlighed kan man således passere fra et virkelighedsniveau til et andet ud fra antagelsen om, at det ene niveau determinerer det andet - og parallelt hermed, ved at antage at målingsfejl følger en normalfordeling, kan man udpege den værdi, der korresponderer med en objektiv astronomisk størrelse (Hack- ing 1990:kap. 13; Desrosières 1991:202). Da Quetelet overførte disse objektiveringsprincipper på menneskelig variation og "moralske fakta", viste han ikke bare vejen for en ny statistisk videnskab, men også for en empirisk makrosociologi, der kunne tilegne sig samfundet som et selvstændigt genstandsfelt. Med introduktionen af "Store Tals Lov" som et grundlæggende aksiom, gjorde han det muligt at hæve sig over det umiddelbare kaos af individuelle hændelser og beskrive dem som tilfældigt fordelte gentagede effekter af bagvedliggende konstante årsager (ækvivalent til urnens konstante komposition). Med appliceringen af binomialfordelingen og Gauss' fejlkurve på moralske og fysiske fakta, konstruerede han endvidere teorien om Homme Moyen, gennemsnitsmennesket og hævdede, at den sociale orden var funderet i dette "fiktive væsen"; samfundets "type" i forhold til hvilken individuelle manifestationer (mennesker og deres handlinger) er at ligne med "stikprøver", kopier af en sand model (i lighed med urnens sande komposition), tilføjet et normalfordelt fejlelement (Porter 1997; Desrosières 1991; 1998).

Med sandsynlighedsteori og astronomisk målingsteori spaltede Quetelet således den sociale virkelighed og kunne dermed præsentere objekter, der ikke vedrørte individuelle handlinger og deres motiver, men derimod beskrev samfundet og dets love som et selvstændigt virkelighedsniveau (Desrosières 1998:68). Fra dette perspektiv, der anskuer mennesket en masse, forsvinder individuelle særheder og tilfældigheder og efterlader et makrosociologisk billede af "generelle [konstante] årsager gennem hvilke samfundet eksisterer og bevares" (Quetelet i Porter 1997:220).

Durkheim overtog, blandt meget andet, Quetelets begreb om gennemsnitstypen, som han lignede med det normale 
og det sunde, og som derfor skulle udgøre sociologiens umiddelbare genstand (Durkheim 1972:61-62, 74). Han fandt også her ideen om, at analyser af statistiske regulariteter kunne anvendes til at isolere den sociale virkeligheds egne lovmæssigheder (ækvivalente til Quetelets konstante årsager). Dermed videreførte han princippet om, at sociologen, for at nå ind til det sociale, må passere gennem det normale, der, udtrykt i konstante gennemsnit og rater, netop angiver muligheden for at isolere dette bagvedliggende niveau, de egentlige sociale fakta (Porter 1997:232; Durkheim 1996:318; 1982:202) ${ }^{5}$.

Både Quetelets Homme Moyen og Durkheims "sociale norm" kan anskues som begrebslige værktøjer, der muliggør en kognitiv sammenbinding af det partikulære og det generelle, der i statistiske tabeller udtrykker sig som forholdet mellem den individuelle handling og aggregatets konstante rater. For Quetelet var begrebet om Homme Moyen i sig selv en forklaring på dette forhold: et individ handler, i gennemsnittet, i overensstemmelse med sin sociale type (Turner 1986: 108). Durkheim derimod afviste Homme Moyen som en forklarende variabel og hævdede, at gennemsnitstypens stabilitet $\mathrm{i}$ virkeligheden var det, der skulle forklares; gennemsnit og rater viser ikke i sig selv, hvorfor en mangfoldighed af individer, uafhængigt af hinanden, realiserer en stabilitet, der viser sig i aggregatet. Det forklarende bindeled mellem individuelle manifestationer og den sociale orden søgte Durkheim i stedet at besvare i termer af social tvang og kollektive kræfter: "uafhængige sociale fænomener", der påvirker individerne udefra.

[A]ll these individual manifestations, however independent of one another they seem, must surely actually result from a single cause or a single group of causes, which dominate individuals. Otherwise how could we explain that all these individual wills, ignorant of one another's existence, annually achieve the same end in the same numbers? [ ...] This regular recurrence of identical events in proportions constant within the same population but very inconstant from one population to another would be inexplicable had not each society definite currents impelling its inhabitants with a definite force... (Durkheim 1996:304-306).

Med disse begreber etablerede Durkheim sammenhængen mellem stabile gennemsnit og individuelle handlinger via en funktionalistisk forklaringsmatrice. Sociale fænomener gentager sig, hævdede Durkheim, ikke fordi de kopierer en "type", men fordi de udfylder en samfundsmæssig funktion, der realiserer sig gennem individuelle handlinger; fremtvunget af kollektive kræfter som opererer i overensstemmelse med den sociale organismes behov. Forklaringen på regulariteten i eksempelvis selvmord og kriminalitet, er således, at disse hændelser er forbundet med og medvirker til opretholdelsen af den sociale integration og dermed til bevarelsen af samfundet: det er netop det, der gør disse umiddelbart individuelle og kontingente fænomener sociale (Durkheim 1996:361ff.; Hacking 1990:kap 20).

Durkheim introducerede en ny terminologi til beskrivelsen af makrosociologiske objekter, men gælden til Quetelet og hans sandsynlighedsteoretiske gentagelseskoncept viser sig tydeligt derved, at for sociologien kan individuelle hændelser først henregnes til det sociale i det øjeblik, de refererer til en bagvedliggende objektiv fællesnævner af en højere virkelighedskarakter, en "kollektiv kraft" eller "social struktur", der, ækvivalent til ur- 
nens konstante komposition, fremtvinger en orden, der viser sig på aggregatets niveau. Det, der gør individuelle manifestationer til sociale fænomener, og ikke til, eksempelvis psykologiske, er netop at de, jf. ovenstående citat, kan betragtes som gentagelser fremtvunget af udefrakommende kollektive kræfter, der opererer i overensstemmelse med samfundsorganismens funktionsbehov. Dette perspektiv på forholdet mellem det sociale som realitet og gentagelsen som fænomen udtrykte han måske mest eksplicit i en kritik af Tardes brug af begrebet social gentagelse (imitation):

\begin{abstract}
[I]mitationen... udtrykker [aldrig] det, der er væsentligt og karakteristisk i det sociale forhold. Selvfølgelig er ethvert socialt forhold imiteret, det har... en tendens til generalisation, men det er fordi det er socialt, dvs. obligatorisk. Dets udbredelsesevne er ikke årsag til, men konsekvens af dets sociologiske karakter... Desuden kan man stille sig selv det spørgsmål, om ordet imitation nu også er det rigtige til at beskrive en spredning, som skyldes en tvingende indflydelse (Durkheim 1972:130-131, note 13).
\end{abstract}

\section{Staten i det sociale}

Med sit funktionalistiske forklaringsskema bevægede Durkheim sig væk fra positivismen og mod en form for symptomafledt realisme, der så statistiske regulariteter som blot det empiriske udtryk for tilstedeværelsen af en totalitet af en højere orden. Fra gentagelsesbegrebets perspektiv betyder dette, at den sociale gentagelses begrundelse placeres uden for dens eget positive moment, hvorved det faktuelle får karakter af noget ufuldendt; som var virkeligheden blot en tilnærmelse til sin egen essens. Indstiftel- sen af dette realitetshierarki er ikke bare af epistemologisk karakter, men kan også relateres til Durkheims læsning af Rousseau og dennes skelnen mellem alles vilje og Almenviljen (Desrosières 1998:101). Den første udtrykker blot sammenhobningen af individuelle viljer, hvorimod den anden, ifølge Durkheim, er en
Fixed and constant orientation of minds and activities in a definite direction, that of the general good. It is a chronic inclination on the part of individuel subjects." (Durk- heim i Desrosières 1998:101).

Durkheims skelnen mellem gentagelsens empiriske manifestation og dens bagvedliggende årsag bliver dermed ikke bare et metodisk spørgsmål (årsag/effekt), men får også en politisk dimension, der skal ses i sammenhæng med hans placering i den cartesianske konfiguration og hans involvering i udformningen af et verdsligt regeringsprincip for den Tredje Republik. Afstanden mellem det manifeste og den bagvedliggende objektivitet, nødvendiggør en intim relation mellem det sociale og staten, der som "hjernen" i samfundet skal udfylde rollen som det sociales realiseringsmodel og (som hos Rousseau) føre det faktuelle kollektiv mod dets egen essens.

For Durkheim bliver det sociale således ikke bare tænkt som et vidensobjekt, men kommer også til at besidde en egen instrumentel værdi, som et realitetsprincip for statslig intervention. Han kritiserede da netop også Tarde for ikke at være i stand til at objektivere det sociale i og med et perspektiv for statens positive rolle. Tardes teori var, sagde Durkheim: "at best capable of showing us what is possible and impossible, but incapable of use for the positive regulation of conduct. [...] it is not worth the trouble it cost." (Durkheim i Lukes 1973:310). 
Også på et mere grundlæggende epistemologisk niveau er Durkheims sociale virkelighed intimt forbundet med staten. Durkheims symptomafledte realisme nødvendiggør et "ydre indeks", hvorigennem den sociale virkelighed kan vise sig for videnskaben. Dette "indeks" fandtes ifølge Durkheim allerede i statens politiske symbolarbejde: juridiske koder og officiel statistik (Giddens 1978:23; Schmaus 1994:38-42).

Disse objekter, hævdede han, udtrykte det sociales materielle udkrystallisering. Konsekvensen af dette metodiske princip er selvfølgelig, at det sociales mulighedsfelt begrænses a priori, da det altid kun kan referere til et politisk homogeniseret interiør af statssanktionerede relationer. Men man kunne måske hævde, med Durkheims placering i den cartesianske konfiguration in mente, at en del af hans succes netop bestod i hans evne til at fremvise det sociale som et selvstændigt realitetsniveau, der samtidig understøttede statens universalitet.

Fra et politisk perspektiv kunne den Tredje Republiks statsmænd finde støtte i Durkheims videnskabelige program til at promovere konceptet om "det sociale" som et realitetsprincip for statslig intervention (Donzelot 1991;1995), og fra et videnskabeligt og akademisk-institutionelt perspektiv kommer staten samtidig til at fungere som en instans, der understøtter den sociologiske objektivitet, idet den leverer "stabile" objekter (jf. det "ydre indeks") til denne nye videnskab. Det sociales potentialitet indkapsles nødvendigvis a priori, idet den sociologiske erfaring implicerer statens mellemkomst som en nødvendig "mediering", men en del af Durkheims succes skyldes måske netop, at han formåede at gøre en statsbevarende konservatisme til en metodisk dyd; hvis sociologien skal være en videnskab med et selvstændigt objekt, kan det sociale aldrig flyde uhæmmet ud i historien.

\section{Det sociale som gentagelse: Tarde}

Samfundet løber bestandigt over sine egne bredder. Dette er det grundlæggende princip i Tardes sociologi. Men ved hvilken kraft, og mod hvilket mål? Vi skal finde svaret på begge disse spørgsmål i det, der udgjorde grundstenen i Tardes teoretiske system: gentagelsen, eller, som han betegnede dette fænomen i dets sociale form: imitation ${ }^{6}$. Sammenlignet med udbredte sociologiske grundbegreber som aktør, system eller samfund, fremstår Tardes begreb om imitation, i mere end en forstand, som en betegnelse for noget "mindre", og det er da også derfor, at Gilles Deleuze med rette har beskrevet Tardes teori som en mikrosociologi (Deleuze 1994:314). Denne karakteristik skal dog ikke tages som anledning til endnu engang at henvise Tarde til den psykologisk-individualistiske fælde, som Durkheim og hans efterfølgere ville fange ham i. Tarde afviste rigtignok aggressivt, hvad han kaldte Durkheims "ontologiske illusion", men lige så lidt som han kunne acceptere ideen om det sociale som en ydre tvingende kraft, lige så lidt kunne han tilslutte sig den frie viljes partisaner og forestillingen om et autonomt, lukket individ (Tarde 2001 [1890])

Med sit begreb om imitation, søgte Tarde derimod at udpege et mere grundlæggende realitetsniveau for sociologien end det, der kunne indfanges med kategorier som "individ" og "samfund". Imitation, hævdede Tarde, betegner selve produktionen af det sociale og udgør derfor "det elementære og universelle sociale faktum" (Tarde 1969 [1898]:94). "Imitation... is the essentially social action from which everything proceeds" (Tarde 1962 [1890]:309, note 1). Først når sociologien havde tilegnet sig denne del af virkeligheden, gentagelsens proces i det allermindste, kunne den kalde sig en vi- 
denskab med et eget genstandsfelt.

\section{Imitationens produktion}

Hvad er imitation? I sin elementære form definerer Tarde den sociale gentagelse, eller imitationen, som "Én hjernes påvirkning af en anden" (Tosti 1897:491). Da det sociale liv, ifølge Tarde, består i alle former for inter-mental aktivitet, betegner netop denne proces etableringen af det mest elementære sociale bånd:

two persons... one of whom exerts a mental influence upon the other...is the one essential element in the social life, and... it always consists, at bottom, in an imitation of one by the other (Tarde 2000 [1899]:23).

Hvis det her kan virke paradoksalt, at gøre imitationen til en produktiv og kreativ kraft og til udgangspunktet for en sociologi, og ikke, i bedste fald en inter-psykologi, så skyldes det, at det kun er for den umiddelbare betragtning, at imitation betegner noget statisk, der udspiller sig mellem blot to individer (Deleuze og Guattari 1987:219). På et dybere niveau skal vi forstå imitationer som sociale strømme, eller, med Tarde, imitative stråler; serier af påvirkninger, der spreder sig på kryds og tværs i samfundet og binder et utal af mennesker sammen på tværs af tid og rum.

Social things, which maintain and perpetuate themselves by the individual consciousnesses through which they evolve, are like an ocean wave, which crosses innumerable molecules and seems to animate them even while living from their force." (Tarde 1969 [1894] :120, fremhævning i originalen).

Det er derfor Tardes teori ikke kan redu- ceres til psykologi eller inter-psykologi, som Durkheim ville det. Imitationen refererer rigtignok til én persons mentale påvirkning af en anden, men i og med etableringen af dette sociale bånd forbindes disse individer samtidig til en anonym, brusende socialitet; bølger eller strømme af sociale produkter, der, i ethvert moment af deres realisering, passerer gennem individer for herigennem at sprede sig, som ringe i vandet, indefra og ud, indtil de møder modstand fra andre strømme eller indgår som elementer i nye kombinationer, der igen vil sprede sig... osv. I modsætning til Durkheim implicerer Tardes gentagelseskoncept således ingen distinktion mellem individet og det sociale. Imitationsbegrebet viser tværtimod, at det giver lige så lidt mening at placere det sociale i et eksternt forhold til individet, som at gøre havets bølger eksterne i forhold til de vandmasser de realiserer sig igennem (Tarde 1962 [1894]:120).

Når Tarde insisterer på udforskningen af imitationerne som sociologiens mest grundlæggende analyseniveau, er det netop fordi disse imitative strømme ikke skal forstås som afledte effekter af bagvedliggende årsager eller som symptomer på tilstedeværelsen af en realitet af en højere orden; en "social organisme" eller et universelt individs invariante træk. Imitationerne udtrykker tværtimod selve det sociale liv i dets tilblivelse, og sociologien må derfor forpligtige sig på dette ene virkelighedsniveau. Det var da også Durkheims store fejl, hævdede Tarde, at han ikke ville anerkende imitationernes egen socialiserende effekt og i stedet forsøgte at forklare sociale fænomener med rekurs til en platonisk ide, en bagvedliggende sand model (Tarde 1969 [1894]:117) ${ }^{7}$. Hermed gjorde Durkheim sig ikke bare skyldig i en falsk spaltning af virkeligheden, han tog også for givet det som egentlig skulle forklares: "mil- 
lioner af menneskers similaritet" (Deleuze og Guattari 1987:218, Tarde 2000 [1899]:25). I en tale til den Første In-ternationale Sociologikongres i 1894 udtrykte Tarde sig således:

The truth is that any social thing, a word in a language, a religious rite, a trade secret, an artistic process, a legal provision, a moral maxim, is transmitted and passed not from the social group taken collectively to the individual, but from one individual - parent, teacher, friend, neighbour, comrade - to another individual, and in this passage from one mind to another it is refracted. The totality of these refractions, starting from an initial impulsion due to some anonymous or illustrious inventor, discoverer, innovator or modifier, is all the reality of a social thing at any given moment. Like all reality, this reality changes by imperceptible nuances, but this does not preclude that from the individual variants there emerge a collective result which is almost constant, and which first strikes our attention and gives rise to Mr. Durkheims ontological illusion. (Tarde 1969 [1894]:115, min fremhævning).

Når Tarde af eftertidens teorihistorie ofte kategoriseres som "individualist", skyldes det måske, at man ikke har taget udtalelser som denne bogstaveligt nok. Tardes udsagn om, at al den virkelighed, som sociale fænomener indeholder, udtrykker sig i imitationernes strømme, deres brydninger, sammenstød og modificeringer, er ikke en tilbagevenden til en metodologisk individualisme. Tværtimod beskriver han her blot grundprincippet for en sociologi, der ikke efterlader nogen vir- kelighedsrest til hverken transcendente sociale fakta eller til et universelt individ, der i større eller mindre grad kan siges at stå uden for det sociale. "Hvad er samfundet? Mit svar er: Samfundet er imitation" (Tarde 1962 [1890]:74).

\section{En social kartografi}

Imitation betegner selve det sociale livs spredning, men dette begreb er hos Tarde intimt forbundet med hans to andre hovedbegreber, invention og opposition. Det er karakteristisk, at ingen af disse tre hovedbegreber henviser til en substantiel identitet, men i stedet beskriver procesformer eller operationer, der udspiller sig i det sociale felt: imitation som udbredelsen af en social strøm, opposition som en binarisering af strømme, invention som sammenføringen af strømme (Deleuze og Guattari 1987:219). Man må derfor også karakterisere Tardes sociologi som en forskels-tænkning, idet han afviser at udpege en bagvedliggende identitet for det sociale (eksempelvis "den sociale organisme $\left.{ }^{\prime \prime}\right)$, men i stedet gør det til sociologiens opgave at beskrive sociale fænomeners differentielle element (Alliez 2001, Tosti 1897). Begreberne imitation, invention og opposition kommer derved også til at udgøre grundlaget for en analysestrategi, der kan beskrives som "kartografisk" i sit udgangspunkt, idet samfundet tænkes som en overflade, hvorpå forbindelser, forskydninger, grænsedragninger og sammenstød mellem sociale strømme udspiller sig.

Begrebet opposition refererer hos Tarde til den særlige gentagelsesproces der opstår, når to modsatrettede strømme mødes, og kan manifestere sig som en diskussion, en krig, en klassekamp eller blot som en tøven, der opstår i et individ (Tarde 1969 [1898]:165-74). Som proces er en opposition grundlæggende reaktiv, da den implicerer reproduktion og ikke produktion; den er et "problem", der nødven- 
diggør en "løsning" (en invention).

Inventioner betegner det, som imiteres. En imitation er altid en gentagelse af en invention (en idé, en gestus, en talemåde, et kognitivt skema, en arbejdsmetode, en samværsform etc.), hvis varighed i det sociale felt netop afhænger af dens evne til at afføde imitationer. Det er indlysende, at enhver imitation forudsætter en model, men hos Tarde tilskrives modellen ingen substantiel identitet, da enhver invention i sig selv etableres gennem en sammensætning af imitative serier. "Enhver invention, det være sig teoretisk eller praktisk, er blot en kombination af imitationer." (Tarde 1969 [1902]:153).

Som betegnelse for en social proces henviser begrebet invention således ikke til realiseringen af en identitet, men først og fremmest til en begivenhed (sammenføjningen af elementer), der samtidig er en differentiering (skabelsen af en ny social form). Hvor imitationerne udtrykker det sociale livs spredning, udtrykker inventionerne dets evolutionære transformation - og den ene proces tjener den anden i en uafbrudt cirkulær bevægelse.

Der er altså et "konstruktivistisk" element i Tardes tænkning, idet det sociale livs former tænkes som bestående af elementer mellem hvilke, der ikke a priori er nogen identitet. Dette princip gælder for alle det sociale livs former og derfor også for individet:

In any one, if we look carefully, we will find nothing but a certain number of he and she that have blurred and confounded themselves through their multiplication (Tarde i Latour 2001:8).

En udtømmende redegørelse for Tardes komplekse og noget obskure individbegreb (se eksempelvis Tarde 1962 [1890]: kap. 3; 2001 [1890]:kap. 3 og 4) kan jeg ikke give her. Jeg tror dog at han grund- læggende forsøgte at tænke individet som en ejendelenes problematik, hvormed han udskifter at være med at haves. Som socialt væsen er jeg ikke, men jeg har de elementer, som jeg imiterer. Dette illustrerer også, hvordan distinktionen mellem individet og det sociale afvikles; enhver imitation, opposition eller invention er altid både en "personlig" og en "social" begivenhed.

Med dette udgangspunkt bliver individet hos Tarde tænkt som en "sammensætning" af det sociales imitative serier - en individuering af sociale elementer fra ét unikt perspektiv. Den personlige sammensætning har disse elementer som en slags samlet socialt minde, og indenfor dette mulighedsfelt realiserer identiteten sig - hvis jeg ellers forstår Tarde ret - som en selektiv aktualisering af elementer i en grundlæggende arbitrær konstellation, der konsolideres gennem selvimitation (vane). Identiteten er derfor også kun ét perspektiv, vi kan anlægge på individet. Foruden de elementer, der konstituerer en identitet, besidder personen også et mere diffust sub-selv; en heterogen social masse af potentialiteter og anknytningspunkter, der, i det omfang de henter styrke fra udefrakommende imitationsstrømme (og herigennem aktualiseres), vil modificere eller endda omskabe identiteten med den konsekvens, at individet undergår en social bliven-anden (se eksempelvis Tarde 2001 [1890]:203). Formuleret som en ejendelenes problematik, bliver identiteten således et spørgsmål om komposition (af sociale elementer), og identitetens varighed bliver efterfølgende et spørgsmål om, hvorvidt individets imitation af sine sociale omgivelser bidrager til at understøtte, omforme eller underminere en given komposition: "Identitet skabes og afvikles; den har sine grader" (Tarde 2001 [1890] :129).

Til illustration kan vi eksempelvis ${ }^{9}$ 
forestille os en læge, hvis identitet reproduceres af én konstitutiv imitation (et ønske om at helbrede), men som på et tidspunkt - eksempelvis i det øjeblik han spadserer forbi en banegård - forbindes til en modsatrettet imitationsstrøm (et ønske om at rejse). Der opstår en tøven i lægens selv i det øjeblik, disse to modsatrettede strømme mødes; en tøven, der nødvendigvis har sin begrundelse i det sociale (den ene strøm når ham gennem en række af læger, der går helt tilbage til Hippocrates, den anden forbinder ham til de første rejsende, der satte sig ombord i et køretøj), men som samtidig også sætter identiteten på spil. I en sådan mikrosekvens kunne vi sige at der opstår en modstilling mellem "individet" og "det sociale", men dog kun i det omfang, at disse termer ikke henviser til ontologisk adskilte niveauer, men derimod udelukkende fungerer som fænomenologiske kategorier eller situationsbestemte retningsangivelser på socialitetens ene, altomsluttende plan.

\section{Gentagelse, differentiering}

Den indbyrdes relation mellem det sociales tre procesformer er reguleret af, hvad Tarde definerede som en cirkulær "law of progressive enlargement": inventioner afføder imitationer, der spreder sig i samfundet, hvormed der genereres et stigende antal oppositioner, når modsatrettede imitationsstrømme kolliderer, hvilket igen producerer nye inventioner, hvormed der åbnes op for nye imitative strømme (Clark 1969:22). Bestemmelsen af de tre sociale procesformers interaktion understreger gentagelsens produktive og kreative karakter. Hvor gentagelsen hos Durkheim peger tilbage mod en transcendent orden, peger den hos Tarde fremad mod en stadig differentiering og skabelse.

Heri ligger efter min mening den vigtigste forskel mellem disse to tænkere, og den afspejler samtidig deres placering i henholdsvis den cartesianske og spontanistiske konfiguration. Som tidligere nævnt så Durkheim gentagelsen som en afledt effekt af den sociale organismes funktionsbehov. Gentagelsen bliver derved social, fordi den er "obligatorisk" og skyldes "en tvingende indflydelse". For Tarde derimod er gentagelsen sit eget endemål, sin egen årsag og grund, idet den udfolder selve det sociale liv som en specifik type virkelighedsproduktion. Tarde hævdede, i modsætning til Durkheim, at samfundsmæssig organisering blot er det middel hvorigennem det sociale udfolder sig som imitativ spredning:

Self-propagation and not self-or-
ganisation is the prime demand
of the social as well as of the vital
thing. Organisation is but the
means of which propagation, of
which generative or imitative repe-
tition, is the end." (Tarde 1962
[1890]: 74, fremhævning i origina-
len ).

Tarde og Durkheim er i en vis forstand enige om, at den sociale virkelighed viser sig som gentagelse, men hvor gentagelsen eller imitationen hos Durkheim er en effekt af en transcendent identitets reproduktion, henviser den hos Tarde til det sociales immanente selvproduktion gennem en stadig differentiering. Som det sociale livs motor tjener gentagelsen her grundlæggende variationen og ikke identiteten, idet den betegner den proces, hvorigennem forskellen "skrider frem i forskelliggørelsen" og "sætter sig selv som mål“ (Tarde i Deleuze 1994:314). Hvor Durkheim brugte gentagelsen til at definere det sociale $i$ og med reproduktionen af en orden, var det hos Tarde det begreb, der gjorde det muligt at tænke det sociale som en virkelighed, der udfolder sig $i$ og med den produktive afvikling af identitet: 
The supreme law of imitation seems to be its tendency towards indefinite progression. It seems to impel every discovery or innovation, however futile, including the most insignificant individual innovations, to scatter itself through the whole of the indefinitely broadened social field (Tarde 1962 [1890]: 366, min fremhævning).

[I]t seems as if life ... sought above all to free itself from itself, to break through its own circle ... as if nothing were more essential to it (this is the case with all reality, perhaps), than to rid itself of its very essence. (Tarde 1962 [1890]:54).

\section{En mikrosociologisk metode?}

Men hvordan kan sociologen rent metodisk tilegne sig denne virkelighed? Som udgangspunkt må sociologen først og fremmest besidde en kærlighed til det sociale (Tarde 1969 [1894]:135). Denne kærlighed skal forpligte sociologen til i første omgang, at affirmere selv de mindste sociale fænomener og dernæst undersøge betingelserne for deres fremkomst og deres spredning. Tarde kunne derfor heller ikke stille sig tilfreds med et durkheimsk princip om, at det sociale primært skulle vise sig gennem (stats)sanktionerede koder. Tarde tog udgangspunkt $i$, at ethvert fænomen, der kan imiteres, udgør et socialt faktum, hvilket åbner et uendeligt empirisk felt for den sociologiske analyse.

Tarde kritiserede først og fremmest Durkheim og Quetelet for at gøre social reproduktion og ikke progression til udgangspunktet for den sociologiske analyse (Clark 1969:47). Dette betyder dog ikke en afvisning af "det generelle" som sådan, men det indebærer en omvending af Durkheims realitetshierarki. I det øjeblik der tages udgangspunkt i mikroimi- tationers niveau, fremtræder Quetelet og Durkheims sociale konstanter (Homme Moyen, kollektive kræfter) som ontologiske illusioner: en social institution eller et generaliseret fænomen forudsætter altid et væld af mikroinventioner og imitationer, som gennem minutiøse processer er blevet integrerede og sammensat til en større helhed:

This conception is, in fact, almost the exact opposite of the unilinear evolutionists' notion and of $\mathrm{M}$. Durkheim's. Instead of explaining everything by the supposed supremacy of a law of evolution, which compels collective phenomena to reproduce and repeat themselves indefinitely in a certain order, instead of thus explaining lesser facts by greater, and the part by the whole, - I explain collective resemblances of the whole by the massing together of minute elementary acts - the greater by the lesser and the whole by the part. (Tarde 2000 [1899]:35, note 4).

En forståelse af samfundets generelle sociale kendsgerninger må derfor altid tage sit udgangspunkt i en oprigtig og minutiøs analyse af den sociale forandrings mindste detalje (Tarde 2000 [1899]:93, note 6). Dette betyder selvfølgelig også, at sociologien ikke kan fundere sig i statens globale kategorier eller i en individualistisk forestilling om det frie individs universalitet. Fremkomsten af sådanne sociale fænomener må i sig selv gøres til genstand for en mikrosociologisk analyse ${ }^{10}$.

For instance, it might first be asked, by whom and how the custom was originally introduced and genera lized, among the peasants of certain rural districts in southern France, of 
not saluting the well-to-do proprietors of their neighbourhood" (Tarde 2000 [1899]:93, note 6; se også Deleuze og Guattari 1987: 216).

Tarde plæderede for en slags mikrosociologisk materialisme, hvis genstandsfelt bestod i sociale objekters produktion og transformation i deres bevægelse gennem samfundet. Intentionerne bag dette materialistiske program er måske mest tydelige i hans hyldest til arkæologien. Denne videnskab, skrev Tarde, praktiserede en "ren sociologi", idet den netop satte parentes om det biologisk-psykologiske og udelukkende beskrev det sociales imitative processer i deres sedimenterede objektivitet: "as the personality of those they unearth is impenetrable... they hear, in a certain way, like the Wagnerian ideal, the music without seeing the orchestra of the past" (Tarde 1962 [1890]:101).

At udsagn som dette kunne tolkes som udtryk for en metodologisk individualisme er stadig et mysterium. Men en forståelse af Tardes teorihistoriske skæbne må dog også relateres til karakteren af det "objekt", som han tilbød sin samtid, for måske blev Tardes kærlighed til det sociale samtidig en sociologisk hybris. Tarde delte Durkheims ambition om at gøre studiet af samfundet til en stringent videnskab, men i modsætning til Durkheim definerede Tarde sociologiens genstandsfelt i og med dets egen selvoverskridende bevægelse og dermed underminerede han også sin egen mulighed for at fremvise et teoretisk og empirisk stabilt "objekt", der kunne fungere som centrum for et akademisk netværk af lærestole, tidsskrifter og disciple.

\section{Konklusion}

I det ovenstående har jeg med udgangspunkt i gentagelsesbegrebet skitseret grundmomenter i Durkheim og Tardes divergerende sociologiske teorier.

Durkheims gentagelse er vertikal, den opererer gennem en spaltning af virkeligheden og refererer til reproduktionen af en transcendent objektivitet (de sociale fakta). Denne sociologiske tænkning funderer sig i udstrakt grad på Staten, der udstyrer den sociologiske tanke med et principielt og faktisk interiør - et interiør som sociologien til gengæld universaliserer gennem en særlig type "social realisme".

Tardes gentagelse er horisontal, den refererer til det sociale som immanent produktion af ét revolutionerende plan, hvor distinktionen mellem individ og samfund forsvinder. Jeg har forsøgt at vise, at det er meningsløst at forbinde Tarde med en metodologisk individualisme. Det er måske mere retfærdigt at forbinde hans navn med et særligt sociologisk problem: spørgsmålet om hvordan man kan forbinde videnskabelig stringens med det, som Tarde selv (storladent, men oprigtigt) beskrev, som "kærligheden" til det sociale og dets uendelige differentiering. Denne kærlighed (og ikke idealtypen eller det normale) var netop for Tarde adgangen til det virkelige: "Hvis alt kommer fra identiteten og hvis alt henviser dertil og kommer derfra, hvad er kilden så til den strøm af variation, der betager os" (Tarde 1893:38).

\section{Noter}

1. Artiklen er en lettere bearbejdet version af en kursusopgave til kurset "Sociological analysis" på Sociologisk Institut, KU. Kurset blev forestået af Margareta Bertilsson, som jeg takker for kommentarer og vejledning. Også tak til Steffen Groth, Heine Andersen og en anonym referee fra Dansk Sociologi. Ansvaret for eventuelle fejl og mangler ved artiklen er selvfølgelig forfatterens eget.

2. Disse betegnelser stammer fra Clarks analyse af det franske universitetssystem, og det følgende bygger i det væsentligste på Clark 1973 og 1969. Clark bruger termen 
"kulturel konfiguration", men som han beskriver disse, kunne man udmærket også betegne dem med et nyere begreb som "diskurskoalitioner" (Andersen 2002:15).

3. Allerede i 1961 blev Tarde i en artikel i American Journal of Sociology, beskrevet som "glemt" Hughes 1961.

4. Som det vil fremgå, var gentagelse eller imitation (social gentagelse) Tardes grundbegreb.

5. Som Ian Hacking spidsformulerer det: "Durkheim continued Quetelet's creation of new kinds of reality" (Hacking 1990:xi).

6. Tardes sociologi er funderet i en større kosmologi, som jeg dog ikke vil komme nærmere ind på, men hvis grundkomponent er ideen om "universal repetition".

7. Før Tarde gjorde Durkheim til sin hovedfjende, fremførte han en lignende kritik mod "Quetelet og hans skole". Se Tarde 1962 [1890]:114, 120.

8. Se Latour 2001, der diskuterer Tardes tænkning som "possession philosophy".

9. Eksemplet er inspireret af Tarde 2001 [1890]:372, men er her tillempet nærværende problemstilling.

10. Deleuze har sammenlignet dette perspektiv med Foucaults studier af magtens mikrofysik: "within the overall categories, basic lineages or modern institutions we can still find those microrelations which, far from destroying these larger unities, actually compose them. This is precisely what Gabriel Tarde did when he founded a microsociology: he did not explain the social with reference to the individual; instead he accounted for the all-embracing categories by having recourse to minutely small relations such as "imitation"... or "invention". ..These are the real relations between forces, in so far they transcend mere violence." (Deleuze 1986:36).

\section{Litteratur}

Alliez, E. 2001: Die Aktualität von Gabriel Tarde, Übersetzerpreis zur Förderung der deutsch-französischen Beziehungen (DVA Stiftung, Paris).

Andersen, H. 2002: Samfundsvidenskaber $i$ kontekst. Frederiksberg: Roskilde Universitetsforlag.
Clark, T. 1969: "Introduction". I: Gabriel Tarde: On Communication and Social Influence. Chicago: The University of Chicago Press.

Clark, T. 1973: Prophet and Patrons: The French University and the Emergence of the Social Sciences. Massachusetts: Harvard University Press.

Deleuze, G. 1994: Difference $\mathcal{E}$ Repetition. New York: Columbia University Press.

Deleuze, G. 1986: Foucault. London: Athlone Press.

Deleuze, G. \& Guattari, F. 1987: A Thousand Plateaus, Capitalism and Schizophrenia vol. II. Minneapolis: University of Minnesota Press.

Desrosières, A. 1991: "How to Make Things Which Hold Together: Social Science, Statistics and the State". I: Discourses on Society. Ed.: Wagner, P.; Wittrock, B.; Whitley, R. Dordrecht: Kluwer Academic Publishers.

Desrosières, A. 1998: The Politics of Large Numbers. Cambridge: Harvard University Press.

Donzelot, J. 1991: "The Mobilization of Society". I: G. Burchell, C. Gordon \& P. Miller (eds.): The Foucault Effect. Studies in Governmentality. London: Wheathsheaft Harvester.

Donzelot, J. 1995: "Promoveringen af det sociale". Dansk Sociologi, nr.3/6 årg.

Durkheim, E. 1972: Den sociologiske metode. Odense: Fremad.

Durkheim, E. 1982: "Sociology and the Social Sciences". I: Durkheim, E.: Rules of Sociological Method. London: The Macmillan Press.

Durkheim, E. 1996: Suicide. London: Routledge.

Giddens, A. 1978: Durkheim. London: Fontana Press.

Hacking, I. 1990: The Taming of Chance. Cambridge: Cambridge University Press.

Hughes, E. 1961: “Tardes Psychologie Eqonomique. An Unknown Classic 
by a Forgotten Sociologist". American Journal of Sociology, Vol. 66, 6.: 553559.

Latour, B. 2001(?): “Gabriel Tarde and the End of the Social." http:/ / www.en smp.fr/-latour/Articles/82-TARDE . html

Lazarsfeld, P. 1997: "Quetelet and his "statistique morale"." I: The Classical Tradition in Sociology, The European Tradition. Ed.: Boudon, R.; Cherkaoui, M.; Alexander, J. London: SAGE.

Lukes, S. 1973: Emile Durkheim - His Life and Work. Hammondswath: Penguin Books.

Oberschall, A. 1987: “The Two Empirical Roots of Social Theory and the Probability Revolution". I: The Probalistic Revolution. Vol 2. London: The MIT Press.

Porter, T. 1997: "The Laws That Govern Chaos". I: The Classical Tradition in Sociology, The European Tradition. Ed.: Boudon, R.; Cherkaoui, M.; Alexander, J. London: SAGE.

Schmaus, W. 1994: Durkheims Philosophy of Science and the Sociology of Knowledge. Chicago: The University of Chicago Press.

Tarde, G. 1893: Monadologie et sociologie. http://www.uqac.uquebec.ca/zone 30/Classiques_des_sciences_socia les/index.html

Tarde, G. 1962 [1890]: Laws of Imitation. Gloucester, Mass.: Henry Holt Company.

Tarde, G. 2000 [1899]: Social Laws. Kitchener: Batoche Books. http:/ / socserv.mcmaster.ca/econ/ugcm/ 3113/tarde/laws.pdf

Tarde, G: 2001 [1890]: Penal Philosophy. London: Transaction Publishers.

Tarde, G. 1969 [1902]: “Invention". I: Gabriel Tarde: On communication and Social influence. Chicago: The University of Chicago Press.
Tarde, G. 1969 [1898]: “Opposition“. I: Gabriel Tarde: On Communication and Social Influence. Chicago: The University of Chicago Press.

Tarde, G.: 1969 [1894]: “Sociology, Social Psychology, and Sociologism". I: Gabriel Tarde: On Communication and Social Influence. Chicago: The University of Chicago Press.

Tarde, G. 1969 [1898]: "Sociology“. I: Gabriel Tarde: On Communication and Social Influence. Chicago: The University of Chicago Press.

Thevenot, L. 2000: Which road to follow? The moral complexity of an "equipped" humanity. http://www.ehess. fr/centres/gspm/which-road.pdf

Tosti, G. 1897: "The Sociological Theories of Gabriel Tarde". Political Science Quarterly. Volume 12, 3.:490-511.

Turner, S. 1986: The Search for a Methodology of Social Science. Dordrecht: Kluwer. 